in the maritime industry, it is necessary to conduct a deep analysis of the internal and external environment, which will highlight the strengths and weaknesses of the strategic development of the seaports of Ukraine. The authors have proven that the ports of Ukraine have an attractive investment climate. This is due to the favorable geographical position of Ukraine, the location of transport networks that permeate the entire territory of the country, convenient water areas, the presence of specialists from different industries and the ability of each port to handle various types of cargo quickly enough. So, with the aim of increasing cargo turnover, expanding its container potential, as well as increasing the number of ship calls both at the ports of Ukraine and the world's leading ports, they are actively continuing to implement investment projects.

УДК 338.434(477.44)

DOI: $10.35340 / 2308-104 X .2021 .90-1-12$

\section{ФІНАНСОВЕ ЗАБЕЗПЕЧЕННЯ ДІЯЛЬНОСТІ ПІДПРИЄМСТВ АГРАРНОГО СЕКТОРА}

\author{
КРУЧИНЕНКО В. А.,
}

здобувач третього рівня вищої освіти спеціальності 051

«Економіка», Херсонський державний аграрно-економічний університет

\section{FINANCIAL SUPPORT OF ACTIVITY OF AGRICULTURAL SECTOR ENTERPRISES}

\author{
KRUCHYNENKO V., \\ Post-graduate Student in the \\ specialty 051 "Economics", \\ Kherson State Agrarian and \\ Economic University
}

\begin{abstract}
В даній науковій роботі визначено зміст категорії «фінансове забезпечення». За допомогою кореляційнорегресійного аналізу встановлено значущість джерел фінансового забезпечення розвитку аграрного сектору. Сформовані моделі множинної регресії, які описують залежність параметрів такого розвитку $i$ обсягів ресурсів за різними джерелами фінансового забезпечення.
\end{abstract}

Ключові слова: фінансове забезпечення, підприємства, аграрний сектор, кореляційно-регресійний аналіз, ресурси.

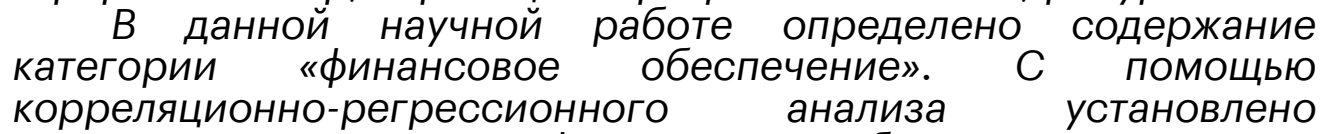
значимость источников финансового обеспечения развития аграрного сектора. Сформированны модели множественной регрессии, описывающие зависимость параметров такого развития и объемов ресурсов по источникам финансового обеспечения.

Ключевые слова: финансовое обеспечение, предприятия, аграрный сектор, корреляционно-регрессионный анализ, ресурсы.

In this scientific work the content of the category "financial support" is defined. With the help of correlation-regression 
analysis, the significance of sources of financial support for the development of the agricultural sector has been established. Multiple regression models are formed, which describe the dependence of the parameters of such development and the amount of resources on different sources of financial security.

Key words: financial provision, enterprises, agricultural sector, correlation-regression analysis, resources.

Постановка проблеми. Аграрний сектор займає стратегічне положення в економіці будь-якої держави, оскільки сільське господарство виступає в якості основної продуктивної системи, яка забезпечує безперебійне надання громадянам продуктів харчування і товарів першої необхідності. Без останніх взагалі неможливе забезпечення процесу життєдіяльності будь-якого соціуму.

Показовим індикатором ролі аграрного сектору в економіці держави $є$ відсоток активної частини соціуму, зайнятого в сільському господарстві, а також питома вага продукції, виробленої в такому господарстві, в структурі внутрішнього валового продукту держави. Ці параметри характеризують стан аграрного виробництва і щорічно змінюються в залежності від ряду факторів, основним з яких $\epsilon$ фінансове забезпечення.

Аналіз останніх досліджень і публікацій. Зважаючи на той факт, що аграрний напрямок $\epsilon$ досить ресурсомістким, проблеми пошуку джерел фінансування, використання яких може забезпечити реалізацію виробничого циклу на якісному і технологічно новому рівні, потребують найскорішого вирішення. Спроби такого вирішення зроблені В. М. Алексійчуком, В. Я. Амбросовим, Л.М.Болдирєвою, М. М. Бучнєвим, О. Є.Гудзь, О.В.Дмитриком, І. В. Застрожніковою, В. К. Збарським, О. М. Ільчуком, М.Ф. Кропивко, Ю. П. Макаренко, О. С. Потаповим, М. І. Пугачовим, П. А. Стецюком, П. Т. Саблуком [1-3, $5,7,9,11-14,16-19]$ та іншими науковцями. В той же час, в полі зору більшості вчених знаходяться питання, які потребують вирішення в окремо обраному сегменті аграрного сектору або сполучені 3 використанням конкретного джерела фінансових ресурсів. Масштабність проблеми недофінансування діяльності суб'єктів аграрного сектору, її сполученість з проблематикою забезпечення продовольчої безпеки та багатьма іншими визначає необхідність застосування комплексного підходу до ії вирішення. Це стосується формування сукупності заходів 3 акумуляції фінансових ресурсів, оптимізації їх пропорцій, обґрунтування напрямків використання для забезпечення ефективного результату як для аграрного сектору, так і для суспільства в цілому. Поєднання таких заходів в систему стратегічної дії передбачає необхідність встановлення стратегічної значущості джерел фінансового забезпечення, що визначається результативністю їх використання в частині формування основних параметрів розвитку аграрного сектору - активної частини соціуму, зайнятого в сільському господарстві, а також обсягу виробленого валового внутрішнього продукту.

Таким чином, метою даної статті $€$ встановлення значущості джерел фінансового забезпечення розвитку аграрного сектору 3 точки зору ефективності функціонування останнього.

Виклад основного матеріалу дослідження. Детальне вивчення наукової спадщини, представленої в роботах Я.Буздугана, Т. Гавриленко, Л. В. Дікань, М. Забаштанського, Г. Погріщука, 
В. Савчука $[4,6,8,10,20,21]$ дозволяє відзначити неоднозначність сприйняття науковцями змісту категорії «фінансове забезпечення». Критичний огляд представлених в літературі визначень свідчить про можливість систематизації викладених в ній підходів. Результатом такої систематизації $€$ встановлення двох основних точок зору щодо змісту фінансового забезпечення: 3 одного боку, фінансове забезпечення може сприйматися як сукупність фінансових ресурсів, використання яких створюе умови реалізації виробничих, організаційних, соціальних та інших процесів, а 3 іншого - як комплекс організаційно-управлінських рішень та заходів, що забезпечують акумуляцію, розподіл та використання фінансових ресурсів для формування умов розвитку відповідних процесів $[4,6,8$, $10,20,21]$. Тобто в першому випадку забезпечення ототожнюється 3 ресурсами, в другому - 3 оперуванням цими ресурсами. I в обох випадках обсяги і структура ресурсів $€$ найважливішими характеристиками фінансового забезпечення.

Безумовно, в кожній сфері діяльності існують свої особливості використання ресурсів, що в значній мірі визначаються значущістю тієї чи іншої групи таких ресурсів для досягнення результату. Для встановлення значущості окремих груп фінансових ресурсів в частині забезпечення ефективності їх використання в аграрній сфері можуть бути використані інструменти кореляційно-регресійного аналізу. Використання таких інструментів в економічній статистиці та економетриці задля вивчення зв'язку між вибірками показників дуже поширене: в тому випадку коли зв'язок між ними носить не функціональний, а імовірнісний (або стохастичний) характер, а однозначної залежності між величинами немає, в процесі розрахунків застосовуються методи кореляції і регресії. Їх використання дозволяє встановити наявність і ступінь зв'язку між величинами $X$ і $Y$.

В якості міри такого зв'язку використовується коефіцієнт кореляції, який оцінюється за вибіркою обсягу $n$ пов'язаних пар спостережень $\left(X_{i}, Y_{i}\right)$ із генеральної сукупності $X$ і $Y$. Для оцінки ступеня взаємозв'язку величин $X$ і $Y$, виміряних в кількісних шкалах, використовується коефіцієнт лінійної кореляції, який передбачає, що вибірки $X$ і $Y$ розподілені за нормальним законом. Лінійний коефіцієнт кореляції - параметр, який характеризує ступінь лінійного взаємозв'язку між двома вибірками, розраховується за формулою:

$$
r_{X Y}=\frac{\sum\left(X_{i}-\bar{X}\right) \times\left(Y_{i}-\bar{Y}\right)}{\sqrt{\sum\left(X_{i}-\bar{X}\right)^{2} \times \sum\left(Y_{i}-\bar{Y}\right)^{2}}}
$$

де $X_{i}$ - значення, що приймаються в вибірці $X$,

$Y_{i}$ - значення, що приймаються в вибірці $Y$,

$\bar{X}$ - середня по $X$,

$\bar{Y}$ - середня по $Y$.

Коефіцієнт кореляції змінюється від -1 до 1.

Моделювання вимірюваних даних і дослідження їх властивостей дозволяє здійснити метод регресійного аналізу. Його застосування потребує встановлення значень залежної змінної і незалежної змінної. Регресійна модель $€$ економіко-статистичною моделлю, що базується на рівнянні регресії або системі регресійних рівнянь, в яких пов'язано 
величини екзогенних (вхідних, «пояснюючих») та ендогенних (вихідних) змінних.

Найчастіше регресія задається рівнянням, яке показує залежність між двома групами числових змінних.

В якості основного показника, що відображає міру якості регресійної моделі, яка описує зв'язок між залежною і незалежними змінними, використовується коефіцієнт детермінації.

Перш ніж оцінити значущість окремих груп ресурсів для забезпечення розвитку аграрного сектору, доцільно встановити наявність зв'язку між характеристиками такого розвитку і обсягом фінансового забезпечення взагалі. В якості основних параметричних характеристик можуть бути обрані: валовий внутрішній продукт у фактичних цінах у розрахунку на одну особу і кількість зайнятих у відповідній сфері. Період проведення розрахунків - 2010-2017 рр. (табл. 1, 2).

Таблиця 1

Результати кореляційно-регресійного аналізу взаємозв'язку між обсягом фінансування аграрного сектора і ВВП у фактичних цінах у розрахунку на одну особу

\begin{tabular}{|c|c|c|}
\hline & $\begin{array}{c}\text { Обсяг фінансових } \\
\text { ресурсів, млн. грн. }(X)\end{array}$ & $\begin{array}{c}\text { Валовий внутрішній } \\
\text { продукт аграрного сектору } \\
\text { у фактичних цінах у } \\
\text { розрахунку на одну особу } \\
(Y)\end{array}$ \\
\hline 2010 & 172364,6 & 24798,0 \\
\hline 2011 & 228308,2 & 29980,0 \\
\hline 2012 & 276651,8 & 32480,0 \\
\hline 2013 & 313096,8 & 33965,0 \\
\hline 2014 & 390607,0 & 36904,0 \\
\hline 2015 & 685844,9 & 46413,0 \\
\hline 2016 & 1537319,1 & 55899,0 \\
\hline 2017 & 911614,1 & 70233,0 \\
\hline $\begin{array}{l}\text { Коефіцієнт } \\
\text { кореляції }\end{array}$ & \multicolumn{2}{|r|}{0,809} \\
\hline $\begin{array}{l}\text { Коефіцієнт } \\
\text { детермінації }\end{array}$ & \multicolumn{2}{|c|}{0,6541} \\
\hline Рівняння регресії & \multicolumn{2}{|c|}{$0,026 X+26417,76$} \\
\hline
\end{tabular}

Результати кореляційно-регресійного аналізу взаємозв'язку між обсягом фінансування аграрного сектора і ВВП у фактичних цінах у розрахунку на одну особу свідчать про наявність високого прямого зв'язку між цими факторами (коефіцієнт кореляції становив 0,809). Перевірка статистичної значущості рівняння за допомогою коефіцієнту детермінації дозволяє відзначити, що 65, 41\% загальної варіабельності ВВП аграрного сектору у фактичних цінах у розрахунку на одну особу пояснюється зміною обсягу фінансових ресурсів.

Результати кореляційно-регресійного аналізу взаємозв'язку між обсягом фінансування аграрного сектора і кількістю зайнятих у ньому осіб свідчать про наявність високого зворотного зв'язку між цими факторами (коефіцієнт кореляції становив - 0,755). Перевірка статистичної значущості рівняння за допомогою коефіцієнту детермінації дозволяє відзначити, що 57,03\% загальної варіабельності кількості зайнятих пояснюється зміною обсягу фінансових ресурсів. 
Іншими словами - точність підбору рівняння регресії середня. Останні 42,97\% зміни кількості зайнятих пояснюються факторами, не врахованими в моделі.

Таблиця 2

Результати кореляційно-регресійного аналізу взаємозв'язку між обсягом фінансування аграрного сектора і кількістю зайнятих у ньому осі6

\begin{tabular}{|c|c|c|}
\hline & $\begin{array}{c}\text { Обсяг фінансових } \\
\text { ресурсів, млн. грн. }(X)\end{array}$ & $\begin{array}{c}\text { Кількість зайнятих, тис. } \\
\text { осіб }(Y)\end{array}$ \\
\hline 2010 & 172364,6 & 3115,6 \\
\hline 2011 & 228308,2 & 3410,3 \\
\hline 2012 & 276651,8 & 3308,5 \\
\hline 2013 & 313096,8 & 3389,0 \\
\hline 2014 & 390607,0 & 2891,4 \\
\hline 2015 & 685844,9 & 2866,5 \\
\hline 2016 & 1537319,1 & 2860,7 \\
\hline 2017 & 911614,1 & $-0,755$ \\
\hline $\begin{array}{l}\text { Коефіцієнт } \\
\text { кореляції }\end{array}$ & \multicolumn{2}{|c|}{0,5703} \\
\hline $\begin{array}{l}\text { Коефіцієнт } \\
\text { детермінації }\end{array}$ & \multicolumn{2}{|c|}{$y=-0,00038 X+3328,68$} \\
\hline Рівняння регресії & \multicolumn{2}{|c|}{} \\
\hline
\end{tabular}

В цілому, результати кореляційно-регресійного аналізу зв'язку між обсягом валового внутрішнього продукту, кількістю зайнятих в аграрному секторі як характеристиками розвитку аграрного сектору і обсягом фінансових ресурсів, спрямованих на такий розвиток, дозволяє відзначити наступне: фінансові ресурси $є$ фактором впливу на розвиток аграрної сфери; для пояснення тенденцій такого розвитку має бути використано рівняння 3 більшою кількістю пояснюючих. Таку конкретизацію може забезпечити формування моделі множинної регресії.

Встановлення наявності зв'язку між обраними показниками свідчить про доцільність конкретизації факторів фінансового забезпечення для встановлення їх вагомості. В таблицях 3 і 5 представлені результати розрахунку параметрів множинної регресії. Емпіричне рівняння у даному випадку має вигляд:

$$
Y=b_{0}+b_{1} \times X_{1}+\cdots+b_{m} \times X_{m}+e
$$

де X1, X2 Xm - незалежні змінні;

b0, b1, ..., bm - значення коефіцієнтів регресії;

e - оцінка відхилення $\varepsilon$.

Розраховане значення множинного коефіцієнту кореляції (табл. 3) свідчить про наявність тісного зв'язку між обсягами валового внутрішнього продукту і параметрами фінансового забезпечення обсягами банківського кредитування, державної підтримки, іноземних інвестицій, нерозподіленого прибутку.

Побудова рівняння множинної регресії сполучена з обчисленням приватних коефіцієнтів кореляції. Коефіцієнт приватної кореляції відрізняється від простого коефіцієнта лінійної парної кореляції тим, що він характеризує парну кореляцію відповідних ознак (Y і Xi) за умови, що вплив на них інших факторів $(\mathrm{Xj})$ усунуто. 
Таблиця 3

Результати кореляційно-регресійного аналізу взаємозв'язку між

валовим внутрішнім продуктом у фактичних цінах і обсягами

фінансового забезпечення діяльності аграрного сектору в розрізі його джерел

\begin{tabular}{|c|c|c|c|c|c|}
\hline & $\begin{array}{c}\text { Валовий } \\
\text { внутрішній } \\
\text { подукт у } \\
\text { фактичних } \\
\text { цінах у } \\
\text { розрахунку } \\
\text { на одну } \\
\text { особу (Y) }\end{array}$ & $\begin{array}{c}\text { Обсяг } \\
\text { банківського } \\
\text { кредиту- } \\
\text { вання (X1) }\end{array}$ & $\begin{array}{c}\text { Обсяг } \\
\text { державної } \\
\text { підтримки } \\
\text { (Х2) }\end{array}$ & $\begin{array}{l}\text { Обсяг } \\
\text { іноземних } \\
\text { інвестицій } \\
\text { (Х3) }\end{array}$ & $\begin{array}{l}\text { Нероз- } \\
\text { поділе- } \\
\text { ний } \\
\text { прибуток } \\
\text { (Х4) }\end{array}$ \\
\hline 2010 & 24798,0 & 26880,0 & 4608,1 & 5399,4 & 41605,2 \\
\hline 2011 & 29980,0 & 34080,0 & 4327,9 & 5821,9 & 62218,6 \\
\hline 2012 & 32480,0 & 37810,0 & 6457,7 & 5883,8 & 80223,8 \\
\hline 2013 & 33965,0 & 40170,0 & 7310,1 & 5825,3 & 85421,7 \\
\hline 2014 & 36904,0 & 53070,0 & 16212,2 & 9234,7 & 90132,1 \\
\hline 2015 & 46413,0 & 48430,0 & 45775,0 & 13478,2 & 189692,1 \\
\hline 2016 & 55899,0 & 55370,0 & 6929,3 & 12831,9 & 262375,6 \\
\hline 2017 & 70233,0 & 59700,0 & 5032,0 & 15519,9 & 318501,0 \\
\hline $\begin{array}{l}\text { Множинний } \\
\text { коефіцієнтт } \\
\text { кореляції }\end{array}$ & \multicolumn{5}{|c|}{0,9943} \\
\hline $\begin{array}{l}\text { Коефіцієнт } \\
\text { детермінації }\end{array}$ & \multicolumn{5}{|c|}{0,9886} \\
\hline $\begin{array}{l}\text { Рівняння } \\
\text { регресії }\end{array}$ & \multicolumn{5}{|c|}{$Y=12820,36+0,2012 X_{1}-0,1115 X_{2}+0,6592 X_{3}+0,1049 X_{4}$} \\
\hline
\end{tabular}

На підставі приватних коефіцієнтів (табл. 4) можна зробити висновок про обґрунтованість включення змінних в регресійну модель. Якщо значення коефіцієнта мале або він незначний, то це означає, що зв'язок між даними фактором і результативною змінною або дуже слабкий, або зовсім відсутній, тому фактор можна виключити з моделі.

Як можна бачити 3 результатів розрахунку приватних коефіцієнтів кореляції, майже незначний зв'язок з представлених форм фінансового забезпечення із валовим внутрішнім продуктом має державна фінансова підтримка, що свідчить про нераціональність державної політики в частині використання державних інструментів впливу задля розвитку сільського господарства. 3 іншими формами фінансового забезпечення державна фінансова підтримка також не має тісного зв'язку.

Таблиця 4

Матриця парних коефіцієнтів кореляції між валовим внутрішнім продуктом у фактичних цінах і фінансовим забезпеченням діяльності аграрного сектора в розрізі його джерел

\begin{tabular}{|l|c|c|c|c|c|}
\hline- & & $X 1$ & $X 2$ & $X 3$ & $X 4$ \\
\hline$Y$ & 1 & 0,8826 & 0,1131 & 0,9348 & 0,9887 \\
\hline$X 1$ & 0,8826 & 1 & 0,2427 & 0,8787 & 0,8468 \\
\hline$X 2$ & 0,1131 & 0,2427 & 1 & 0,4164 & 0,1488 \\
\hline
\end{tabular}


Продовження табл. 4

\begin{tabular}{|c|c|c|c|c|c|}
\hline$X_{3}$ & 0,9348 & 0,8787 & 0,4164 & 1 & 0,9412 \\
\hline$X_{4}$ & 0,9887 & 0,8468 & 0,1488 & 0,9412 & 1 \\
\hline
\end{tabular}

Найбільш результативним з точки зору забезпечення зростання обсягів валового внутрішнього продукту $\epsilon$ використання нерозподіленого прибутку вітчизняних підприємств і зарубіжні інвестиції, що свідчить про необхідність використання переваг цих форм при розробці стратегічних напрямків розвитку сільського господарства.

В результаті розрахунків може бути отримане рівняння множинної регресії: $Y=12820,36+0,2012 \times 1-0,1115 X 2+0,6592 \times 3+$ 0,1049X4. За допомогою коефіцієнту детермінації встановлено, що 98,86\% загальної варіабельності $Y$ пояснюється зміною факторів Xj. Таким чином воно може бути використано в процесі прийняття стратегічних рішень щодо фінансового забезпечення розвитку аграрного сектору.

Результати кореляційно-регресійного аналізу взаємозв'язку між кількістю зайнятих і фінансовим забезпеченням діяльності аграрного сектора в розрізі його джерел також свідчать про низьку ефективність використання державної підтримки для розвитку аграрного сектору, зокрема створення нових робочих місць.

Таблиця 5

Результати кореляційно-регресійного аналізу взаємозв'язку між кількістю зайнятих і обсягами фінансового забезпечення діяльності аграрного сектору в розрізі його джерел

\begin{tabular}{|c|c|c|c|c|c|}
\hline & $\begin{array}{c}\text { Кількість } \\
\text { зайнятих, } \\
\text { тис. осіб }\end{array}$ & $\begin{array}{c}\text { Обсяг } \\
\text { банківського } \\
\text { кредиту- } \\
\text { вання (Х1) }\end{array}$ & $\begin{array}{c}\text { Обсяг } \\
\text { державної } \\
\text { підтримки } \\
(\text { Х2) }\end{array}$ & $\begin{array}{c}\text { Обсяг } \\
\text { іноземних } \\
\text { інвестицій } \\
(\text { Х3) }\end{array}$ & $\begin{array}{c}\text { Нероз- } \\
\text { поділе- } \\
\text { ний } \\
\text { прбуток } \\
(\text { Х4) }\end{array}$ \\
\hline 2010 & 3115,6 & 26880 & 4608,1 & 5399,4 & 41605,2 \\
\hline 2011 & 3410,3 & 34080 & 4327,9 & 5821,9 & 62218,6 \\
\hline 2012 & 3308,5 & 37810 & 6457,7 & 5883,8 & 80223,8 \\
\hline 2013 & 3389,0 & 40170 & 7310,1 & 5825,3 & 85421,7 \\
\hline 2014 & 3091,4 & 53070 & 16212,2 & 9234,7 & 90132,1 \\
\hline 2015 & 2870,6 & 48430 & 45775,0 & 13478,2 & 189692,1 \\
\hline 2016 & 2866,5 & 55370 & 6929,3 & 12831,9 & 262375,6 \\
\hline 2017 & 2860,7 & 59700 & 5032,0 & 15519,9 & 318501,0 \\
\hline $\begin{array}{l}\text { Множинний } \\
\text { коефіцієнт } \\
\text { кореляції }\end{array}$ \\
\hline $\begin{array}{l}\text { Коефіцієнт } \\
\text { детермінації }\end{array}$ \\
\hline $\begin{array}{l}\text { Рівняння } \\
\text { регресії }\end{array}$
\end{tabular}

Отримані значення приватних коефіцієнтів кореляції дозволяють зробити висновок про зворотну залежність кількості створених робочих місць від обсягів фінансування в формі банківського кредитування, іноземних інвестицій і нерозподіленого прибутку. Така ситуація може означати спрямованість інвестицій переважно на 
забезпечення процесів автоматизації та механізації виробництва, що призводить до вивільнення робочої сили.

В результаті розрахунків може бути отримане рівняння множинної регресії $Y=3530,98+0,0089 X 1+0,0038 X 2-0,12 X 3+$ 0,0018X4 і встановлено, що 86,82\% загальної варіабельності Y пояснюється зміною факторів $\mathrm{Xj}$, що дозволяє використовувати його в процесі прийняття стратегічних рішень щодо фінансового забезпечення розвитку аграрного сектору.

Таблиця 6

Матриця парних коефіцієнтів кореляції між кількістю зайнятих осіб і фінансовим забезпеченням діяльності аграрного сектора в розрізі його джерел

\begin{tabular}{|c|c|c|c|c|c|}
\hline- & $\mathrm{Y}$ & $\mathrm{X} 1$ & $\mathrm{X} 2$ & $\mathrm{X} 3$ & $\mathrm{X} 4$ \\
\hline $\mathrm{Y}$ & 1 & $-0,7051$ & $-0,4279$ & $-0,9003$ & $-0,8057$ \\
\hline$X_{1}$ & $-0,7051$ & 1 & 0,2427 & 0,8787 & 0,8468 \\
\hline$X_{2}$ & $-0,4279$ & 0,2427 & 1 & 0,4164 & 0,1488 \\
\hline$X_{3}$ & $-0,9003$ & 0,8787 & 0,4164 & 1 & 0,9412 \\
\hline
\end{tabular}

Висновки і перспективи подальших досліджень. В результаті кореляційно-регресійного аналізу свідчать про необхідність врахування значущості нерозподіленого прибутку, іноземних інвестицій і банківського кредитування (у вказаній послідовності) при розробці стратегічних заходів, спрямованих на забезпечення зростання обсягів виробництва в аграрному секторі. При цьому мають бути враховані наслідки надходження відповідних ресурсів у частині забезпечення робочими місцями.

\section{Література:}

1. Алексійчук В. М. Напрями реформування системи кредитного забезпечення в АПК. Економіка АПК. 1998. № 1. С. 40-45.

2. Амбросов В. Я., Онєгіна А. М. Формування кредитного ринку в системі агробізнесу США. Економіка АПК. 2001. № 2. С. 115-116.

3. Болдирєва Л.М. Розвиток агропродовольчого сектора економіки України: теорія, методологія, практика: монографія. Київ: ННЦ «IAE», 2017. 414 c.

4. Буздуган Я. Поняття, принципи, форми фінансового забезпечення охорони здоров'я в Україні. Віче. URL: http://www.viche.info/journal/960/.

5. Бучнев М. М. Розвиток власності та його вплив на підвищення ефективності аграрних підприємств в період інституційних трансформацій: монограф. Одеса: КУПРІЄНКО СВ, 2020. 275 c.

6. Гавриленко Т. В. Фінансове забезпечення діяльності підприємств в сучасних умовах. Міжнародний науковий журнал «Інтернаука». 2016. № 12 (22). 
7. Ґудзь О. Є. Забезпечення сільськогосподарських підприємств кредитними ресурсами. Економіка АПК. 2003. №1. С. 86-90.

8. Дікань Л. В., Голуб Ю. Фінансове забезпечення діяльності підприємства: сутність та джерела. Економіка розвитку. 2007. № 3 (43). C. 65-68.

9. Дмитрик О.В. Організаційно-економічні засади державної підтримки функціонування особистих селянських господарств. Економіка та держава. 2019. № 8. С. 71-75.

10. Забаштанський М. М. Фінансове забезпечення комунальної сфери: автореф. дис. на здобуття наук.ступеня канд. екон. наук: спец. 08.00.08 «Гроші, фінанси, кредит» Ірпінь, 2009. 22 с.

11. Застрожнікова І. В. Державна підтримка інфраструктури села як передумова сталого розвитку сільського господарства країни. Збірник наукових праць Таврійського державного агротехнологічного університету (економічні науки). Мелітополь: Вид-во Мелітопольська типографія «Люкс», 2016. № 1. С. 148-152.

12. Збарський В. К. Соціально-економічні умови розвитку селянських домогосподарств: моногр. Мелітополь: ТДАТУ. Вид-во «Люкс», 2017. 294 с.

13. Ільчук О. М. Державна підтримка сільського господарства в Україні. Економіка АПК. 2019. № 2. С. 93-98.

14. Макаренко Ю. П. Аграрні малі господарства: умови та шляхи розвитку. Дніпропетровськ: Січ. 2012. 680 с.

15. Офіційний сайт Державної служби статистики України. URL: http://ukrstat.gov.ua/operativ/operativ2005/vvp/vvp_ric/vvp_u.htm.

16. Саблук П. Т., Кропивко М. Ф. Напрями поглиблення аграрної реформи на сучасному етапі розвитку АПК. К.: ННЦ «ІАЕ», 2011. 137 с.

17. Потапов О. С. Сільське господарство України: сучасний стан та особливості розвитку Економіка. Фінанси. Менеджмент: актуальні питання науки і практики. 2018. № 9. С. 136-147.

18. Пугачов М. І. Аграрний сектор економіки України в умовах інституційних змін Економіка АПК. 2017. №5. 12-18.

19. Стецюк П. А. Теоретичні основи бюджетного планування сільськогосподарських підприємств. Економіка АПК. 2007. № 1. C. 109-113.

20. Савчук В.А. Фінансове забезпечення виконання функцій держави. Інвестиції: практика та досвід. 2013. № 22. С. 46-49.

21. Погріщук Г.Б. Фінансове забезпечення охорони навколишнього природного середовища: автореф. дис. канд. екон. наук. Тернопіль, 2005. 20 с.

1. Aleksijchuk V. M. Raprjamy reformuvannja systemy kredytnogho zabezpechennja v APK. Ekonomika APK. 1998. \# 1. S. 40-45.

2. Ambrosov V. Ja., Onjeghina A. M. Formuvannja kredytnogho rynku $v$ systemi aghrobiznesu SShA. Ekonomika APK. 2001. \#2. S. $115-116$.

3. Boldyrjeva L. M. Rozvytok aghroprodovoljchogho sektora ekonomiky Ukrajiny: teorija, metodologhija, praktyka: monoghrafija. Kyjiv: NNC "IAE", 2017. 414 s. 
4. Buzdughan Ja. Ponjattja, pryncypy, formy finansovogho zabezpechennja okhorony zdorov'ja $v$ Ukrajini. Viche. URL: http://www.viche.info/journal/960/.

5. Buchnjev M. M. Rozvytok vlasnosti ta jogho vplyv na pidvyshhennja efektyvnosti aghrarnykh pidpryjemstv $v$ period instytucijnykh transformacij: monoghraf. Odesa: KUPRIJeNKO SV, 2020. 275 s.

6. Ghavrylenko T. V. Finansove zabezpechennja dijaljnosti pidpryjemstv $v$ suchasnykh umovakh. Mizhnarodnyj naukovyj zhurnal "Internauka". 2016. \# 12 (22).

7. Gudzj O. Je. Zabezpechennja siljsjkoghospodarsjkykh pidpryjemstv kredytnymy resursamy. Ekonomika APK. 2003. \#1. S. 86-90.

8. Dikanj L. V., Gholub Ju. Finansove zabezpechennja dijaljnosti pidpryjemstva: sutnistj ta dzherela. Ekonomika rozvytku. 2007. \# 3 (43). S. 65-68.

9. Dmytryk O. V. Orghanizacijno-ekonomichni zasady derzhavnoji pidtrymky funkcionuvannja osobystykh seljansjkykh ghospodarstv. Ekonomika ta derzhava. 2019. \# 8. S. 71-75.

10. Zabashtansjkyj M. M. Finansove zabezpechennja komunaljnoji sfery: avtoref. dys. na zdobuttja nauk.stupenja kand. ekon. nauk: spec. 08.00.08 "Ghroshi, finansy, kredyt" Irpinj, 2009. 22 s.

11. Zastrozhnikova I. V. Derzhavna pidtrymka infrastruktury sela jak peredumova stalogho rozvytku siljsjkogho ghospodarstva krajiny. Zbirnyk naukovykh pracj Tavrijsjkogho derzhavnogho aghrotekhnologhichnogho universytetu(ekonomichni nauky). Melitopolj: Vyd-vo Melitopoljsjka typoghrafija "Ljuks", 2016. \# 1. S. 148-152.

12. Zbarsjkyj V.K. Socialjno-ekonomichni umovy rozvytku seljansjkykh domoghospodarstv: monoghr. Melitopolj: TDATU. Vyd-vo "Ljuks", 2017. 294 s.

13. Iljchuk O. M. Derzhavna pidtrymka siljsjkogho ghospodarstva v Ukrajini. Ekonomika APK. 2019. \# 2. S. 93-98.

14. Makarenko Ju. P. Aghrarni mali ghospodarstva: umovy ta shljakhy rozvytku. Dnipropetrovsjk.: Sich. 2012. 680 s.

15. Oficijnyj sajt Derzhavnoji sluzhby statystyky Ukrajiny. URL: http://ukrstat.gov.ua/operativ/operativ2005/vvp/vvp_ric/vvp_u.htm.

16. Sabluk P. T., Kropyvko M. F. Naprjamy poghlyblennja aghrarnoji reformy na suchasnomu etapi rozvytku APK. K.: NNC "IAE", 2011. $137 \mathrm{~s}$.

17. Potapov O. S. Siljsjke ghospodarstvo Ukrajiny: suchasnyj stan ta osoblyvosti rozvytku Ekonomika. Finansy. Menedzhment: aktualjni pytannja nauky i praktyky. 2018. \# 9. S. 136-147.

18. Pughachov M. I. Aghrarnyj sektor ekonomiky Ukrajiny $v$ umovakh instytucijnykh zmin Ekonomika APK. 2017. \#5. 12-18.

19. Stecjuk P. A. Teoretychni osnovy bjudzhetnogho planuvannja siljsjkoghospodarsjkykh pidpryjemstv. Ekonomika APK. 2007. \# 1. S. 109-113.

20. Savchuk V. A. Finansove zabezpechennja vykonannja funkcij derzhavy. Investyciji: praktyka ta dosvid. 2013. \# 22. S. 46-49.

21. Poghrishhuk Gh. B. Finansove zabezpechennja okhorony navkolyshnjogho pryrodnogho seredovyshha: avtoref. dys. kand. ekon. nauk. Ternopilj, 2005. 20 s. 
The agricultural sector occupies a strategic position in the economy of any state, as agriculture acts as the main productive system, which ensures the uninterrupted provision of food and basic necessities to citizens. Without the latter, it is impossible to ensure the vital process of any society.

An indicative indicator of the role of the agricultural sector in the state economy is the percentage of the active part of society engaged in agriculture, as well as the share of products produced in such an economy in the structure of gross domestic product. These parameters characterize the state of agricultural production and change annually depending on a number of factors, the main of which is financial security.

A detailed study of the scientific heritage presented in the works of J. Buzdugan, T. Gavrilenko, LV Dikan, M. Zabashtansky, G. Pogrischuk, V. Savchuk allows us to note the ambiguity of perception scientists of the content of the category "financial support". A critical review of the definitions presented in the literature indicates the possibility of systematizing the approaches set out in it. The result of such systematization is the establishment of two main points of view on the content of financial security: on the one hand, financial security can be perceived as a set of financial resources, the use of which creates conditions for production, organizational, social and other processes, and on the other - as a set of organizational and managerial decisions and measures that ensure the accumulation, distribution and use of financial resources to create the conditions for the development of relevant processes. That is, in the first case, the provision is identified with resources, in the second - with the operation of these resources. In both cases, the volume and structure of resources are the most important characteristics of financial security.

Of course, each area of activity has its own characteristics of resource use, which are largely determined by the importance of a particular group of such resources to achieve results. To establish the significance of certain groups of financial resources in terms of ensuring the effectiveness of their use in the agricultural sector can be used tools of correlation and regression analysis. The use of such tools in economic statistics and econometrics to study the relationship between samples of indicators is very common: in the case when the relationship between them is not functional but probabilistic (or stochastic), and there is no unambiguous relationship between the values in the calculation process correlation and regression methods are used. 